ISSN 0067-1975 (print), ISSN 2201-4349 (online)

https://doi.org/10.3853/j.2201-4349.70.2018.1715

urn:Isid:zoobank.org:pub:62503ED7-0C67-4484-BCE7-E4D81E54A41B

Michael F. Braby (iD) orcid.org/0000-0002-5438-587X

\title{
A new subspecies of Neolucia hobartensis (Miskin, 1890) (Lepidoptera: Lycaenidae) from Mainland Southeastern Australia, with a Review of Butterfly Endemism in Montane Areas in this Region
}

\author{
Michael F. Braby ${ }^{*}$ and Graham E. Wurtz ${ }^{2}$ \\ ${ }^{1}$ Division of Ecology and Evolution, Research School of Biology, The Australian National University, \\ Acton ACT 2601, Australia, and \\ National Research Collections Australia, Australian National Insect Collection, \\ GPO Box 1700, Canberra ACT 2601, Australia \\ 2 Thurgoona NSW 2640, Australia \\ michael.braby@anu.edu.au
}

\begin{abstract}
Neolucia hobartensis albolineata ssp. nov. is illustrated, diagnosed, described and compared with the nominate subspecies $N$. hobartensis hobartensis (Miskin, 1890) from Tasmania and N. hobartensis monticola Waterhouse \& Lyell, 1914 from northern New South Wales, Australia. The new subspecies is restricted to montane areas (mainly $>1000 \mathrm{~m}$ ) in subalpine and alpine habitats on the mainland in southeastern Australia (southern NSW, ACT, VIC) where its larvae specialize on Epacris spp. (Ericaceae). It thus belongs to a distinct set of 22 butterfly taxa that are endemic and narrowly restricted to montane areas $(>600 \mathrm{~m}$, but mainly $>900 \mathrm{~m})$ on the tablelands and plateaus of mainland southeastern Australia. Monitoring of these taxa, including $N$. hobartensis ssp., is urgently required to assess the extent to which global climate change, particularly temperature rise and large-scale fire regimes, are key threatening processes.
\end{abstract}

KEYWORDS. Butterfly conservation; climate change; key threatening processes; Polyommatinae; taxonomy

Braby, Michael F., and Graham E. Wurtz. 2018. A new subspecies of Neolucia hobartensis (Miskin, 1890) (Lepidoptera: Lycaenidae) from mainland southeastern Australia, with a review of butterfly endemism in montane areas in this region. Records of the Australian Museum 70(5): 423-433. https://doi.org/10.3853/j.2201-4349.70.2018.1715

The lycaenid genus Neolucia Waterhouse \& R.E. Turner, 1905 comprises three species all endemic to southern Australia (Braby, 2000). It is currently placed in the subfamily Polyommatinae, a large polyphyletic assemblage nested within the Theclinae (Espeland et al., 2018). Within this group, Neolucia is morphologically distinct with no close relatives (Hirowatari, 1992): the dorsal surface of

* author for correspondence the wings are uniformly dark bronze-brown, the egg is truncate dorsally with three prominent horizontal series of projections, and the larvae feed mainly on Ericaceae (with one species on Fabaceae) and are usually not attended by ants. Neolucia hobartensis (Miskin, 1890), commonly known as the 'Montane Heath-blue', is a polytypic species endemic to southeastern mainland Australia and Tasmania 
(Couchman \& Couchman, 1977; Virtue \& McQuillan, 1994; Braby, 2000; Field, 2013; Bond, 2016). All species of Neolucia occur in montane areas, but $N$. hobartensis is the only species restricted to high altitudes. Indeed, it is one of very few species of butterflies in Australia endemic to subalpine and alpine habitats (i.e. above the tree-line).

Two subspecies of $N$. hobartensis have been recognized: the nominate subspecies $N$. hobartensis hobartensis (Miskin, 1890) from Tasmania, and $N$. hobartensis monticola Waterhouse \& Lyell, 1914 from montane areas in northern New South Wales (Braby, 2000, 2016). Neolucia hobartensis monticola was differentiated by several characters, namely larger size, darker underside ground colour, and darker upperside ground colour (Waterhouse \& Lyell, 1914). Common \& Waterhouse (1981) added that in the male the long hairs (androconia) on the upperside of the fore wing are more extensive. Material between the geographical ranges of these two subspecies (i.e. southern New South Wales, the Australian Capital Territory and Victoria) has been provisionally placed with $N$. hobartensis hobartensis, although Braby (2000, p. 820) noted that "The extent of the whitish patch on the underside of the hind wing varies considerably between populations from southern NSW, VIC and TAS." Closer examination of a large series of specimens from this region, and comparison with the types of both $N$. hobartensis hobartensis and $N$. hobartensis monticola, has revealed that this geographically isolated population(s) is indeed distinct. The purpose of this paper is to describe the population(s) from this intervening region taxonomically. We also review the occurrence of butterflies endemic to the mountains and highlands of southeastern Australia, and comment on the subspecies' restricted occurrence in montane areas and the potential risk of global climate change as a key threatening process.

The following abbreviations refer to repositories where material has been examined:

\section{AMS Australian Museum, Sydney}

ANIC Australian National Insect Collection, Canberra NMV Museum Victoria, Melbourne QM Queensland Museum, Brisbane GEWC Private collection of G. E. Wurtz, Albury

\section{Taxonomy}

\section{Neolucia hobartensis albolineata ssp. nov.}

\author{
Figs $8-11$ \\ urn:Isid:zoobank.org:act:7C95E916-9067-44CF-B0B0-4DC6576E6FE8
}

Holotype o", "Smokers Gap, ACT, 25 DEC. 1998, M.F. Braby" (ANIC). Paratypes 550" $0^{\prime \prime}, 27$ 우. Australian Capital Territory: $\sigma$ " "SMOKER GAP, ACT, 1244 ALT, 6 JAN 1980, NB TINDALE" (ANIC); 4 "SMOKER'S GAP, CORIN DAM, ACT, 26th Jan 1987, GE Wurtz" (GEWC); o" "Smokers Gap, ACT, 12-Jan-1992, EGGLETON" (ANIC); 30', 2 ㅇ "Smokers Gap, ACT, 5 FEB. 1995, M.F. Braby" (ANIC); 50", 3 \% "Smokers Gap, ACT, 25 DEC. 1998, M.F. Braby" (ANIC); 9o", 2 ? "Smokers Gap, ACT, 16 JAN. 1999, M.F. Braby" (ANIC); ๆ "Smokers Gap, ACT, emg. 8 JAN. 1999, pupated 30 DEC. 98, M.F. Braby | reared from larva on EPACRIS BREVIFLORA flowers" (ANIC); ㅇ "Smokers Gap, ACT, emg. 10 JAN. 1999, pupated 31 DEC. 98, M.F. Braby | reared from larva on Epacris breviflora flowers" (ANIC); 9 "Smokers Gap, ACT, emg. 10 JAN. 1999, pupated 1 JAN. 99, M.F. Braby | reared from larva on EPACRIS BREVIFLORA flowers" (ANIC); $\sigma^{7}$ "Mt. Gingera, A.C.T., 24 Jan. 1951, M.F. Day" (ANIC); o" "Mt. Gingera, A.C.T. 6000 ft., 25 Jan. 1956, I.F.B. Common" (ANIC); ㅇ "Mt. Gingera, A.C.T. 5500 ft., 22-1-1956, I.F.B. Common" (ANIC); 30" "Mt. Gingera, A.C.T. 5500 ft., 6 Feb. 1962, I.F.B. Common" (ANIC); 6o" "Mt. Gingera, ACT. 5500 ft., 5 Feb. 1969, I.F.B. Common \& A.E. May" (ANIC); o", 2 \% "Mt. Gingera, A.C.T. 1670 m, Emg. 25 Jan. 1971, E.D. Edwards", “6/71 Larva on flowers Epacris petrophila" (ANIC); $\$$ same data but with date "Emg. 28 Jan. 1971" (ANIC); 40" "1 Ml NE of Lee's Springs, A.C.T. 4000 ft, 30 Jan. 1957, I.F.B. Common" (ANIC); o", 2 ' "Mt. Franklin, ACT. 4800 ft., 5 Feb. 1969, I.F.B. Common \& A.E. May" (ANIC); $10^{7}$ "[3.6 km S by road of] GIBRALTAR FALLS, TIDBINBILLA RGE, ACT, 4th Jan 1980, GE Wurtz" (GEWC); $10^{\star}$ "[3.6 km by road S of] GIBRALTAR FALLS, TIDBINBILLA RGE, ACT, 26th Jan 1987, GE Wurtz” (GEWC); 20" “HONEYSUCKLE CK, ACT, 29th NOV 1980, ANDREW ATKINS" (ANIC); 19 "Honey Suckle Crk, ACT, S 35.35.5, E 148.58, 2nd Feb 1984, GE Wurtz" (GEWC); 2\% "Honeysuckle Ck, Namadgi NP, ACT, 1080 m, 35³5'S, 148 59'E, 15 JAN. 1995, M.F. Braby" (ANIC); 60", o “Brindabella Ra., A.C.T., 21 Jan. 1981, J.F.R. Kerr" (ANIC); 80", 2 " "2 STICKS ROAD, BRINDABELLA RANGE, W. CANBERRA, ACT, 14th Jan 1979, GE Wurtz" (GEWC); o" "2 km NTH of PICCADILLY CIRCUS, A.C.T., 21 JAN. 1984, K.L. DUNN, C.E. ASTON” (ANIC); $\uparrow " 2.2$ km N. Piccadilly Circus, ACT, 12 JAN. 1997, M.F. Braby" (ANIC). New South Wales: 6o", $q$ "E.D. EDWARDS, 25.1.70, Boyd R, N.S.W., AUSTRALIA" (ANIC).

Other material examined An additional 638 specimens from New South Wales and Victoria currently lodged in the

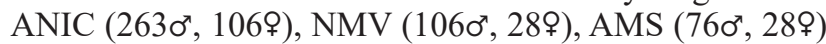
and GEWC (180', 13ㅇ) were examined (Table 1). Locations for these specimens are as follows. New South Wales: South Black Range, Tallaganda NP, 9 km E of Hoskinstown (40*, 2\%); Cumberland Range, Talbingo (20 ); Tinderry

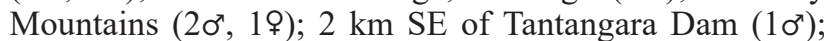
$10 \mathrm{mls}$ E of Kiandra, NSW (20'); $1 \mathrm{~km} \mathrm{~W}$ of Three Mile 


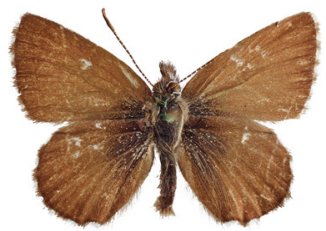

1

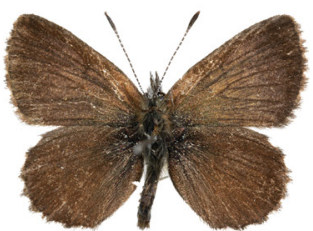

4

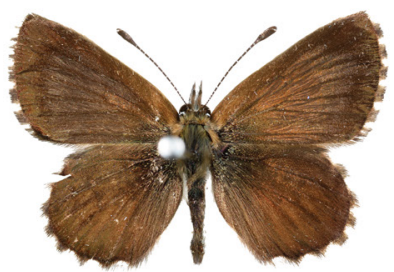

8

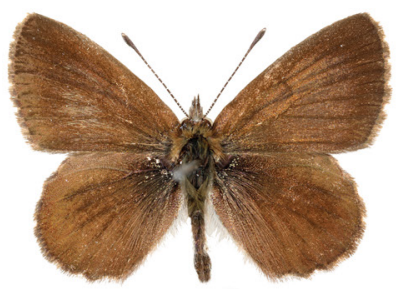

12

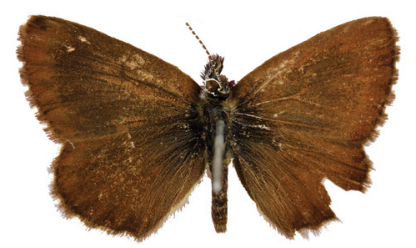

16

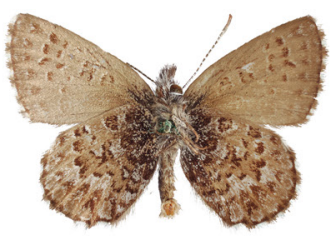

2

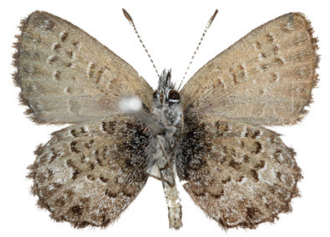

5

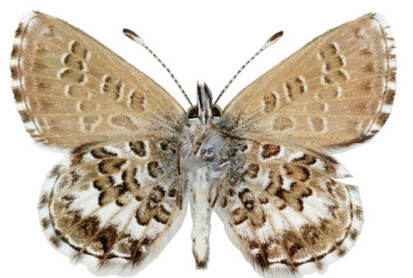

9

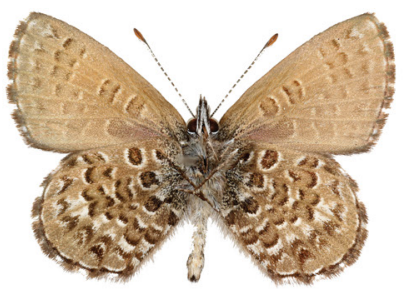

13

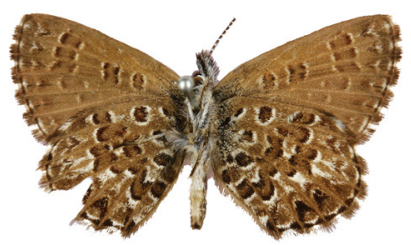

17

$10 \mathrm{~mm}$

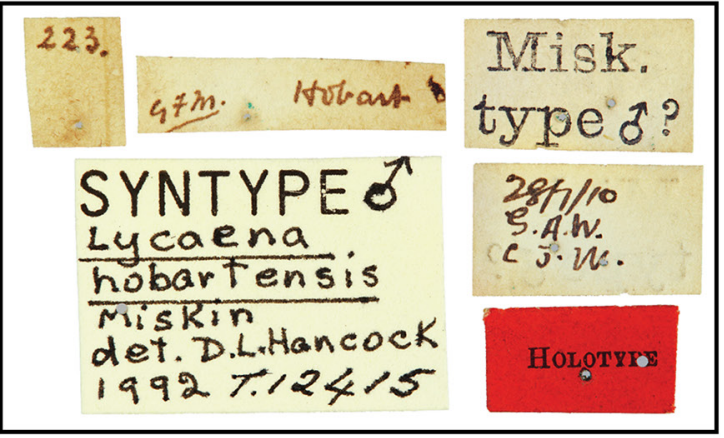

3

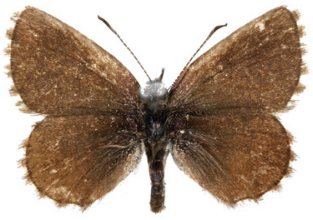

6

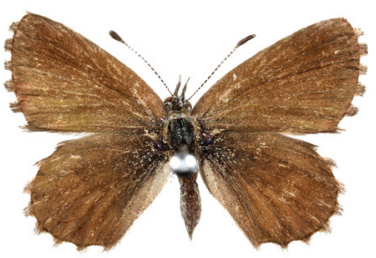

10

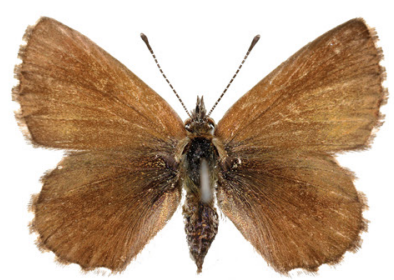

14

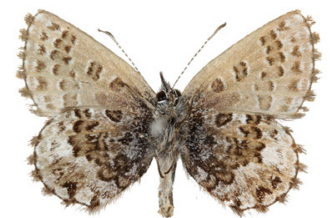

7

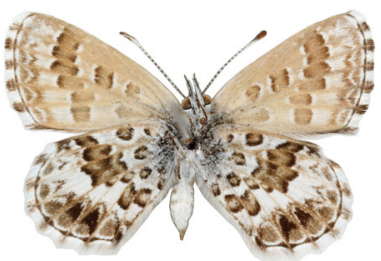

11

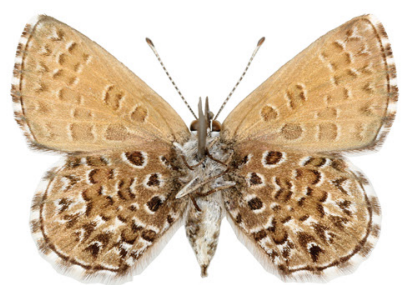

15

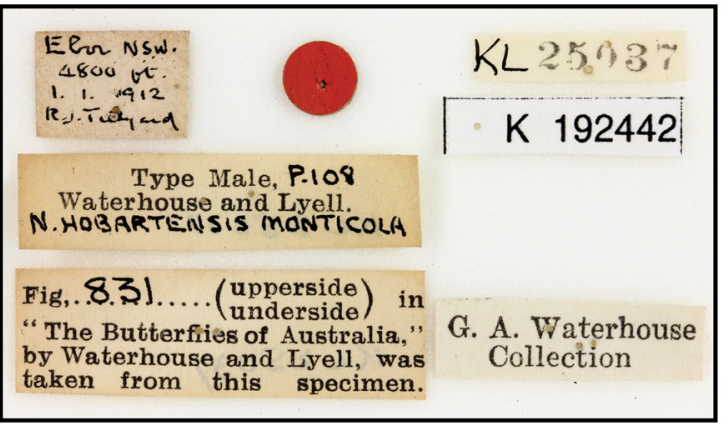

Figures 1-18. Adult specimens of Neolucia hobartensis: (1-3) N. hobartensis hobartensis lectotype male (QM) showing upperside, underside and labels; (4-7) N. hobartensis hobartensis from Tasmania: 4 and 5, male upperside and underside "Pine Tier Lake, TAS, S42.04.14, E146.28.74, 16th Jan. 2013, G.E. Wurtz" (GEWC), 6 and 7, female upperside and underside "Mt. Barrow, T. 4000 ft., 4 Mar. 1963, I.F.B. Common \& M.S. Upton" (ANIC); (8-11) N. hobartensis albolineata ssp. nov. from ACT and southern NSW: 8 and 9, holotype male upperside and underside "Smokers Gap, ACT, 25 DEC. 1998, M.F. Braby" (ANIC), 10 and 11, paratype female upperside and underside "E.D. EDWARDS, 25.1.70, Boyd R, N.S.W., AUSTRALIA" (ANIC); (12-15) N. hobartensis monticola from northern NSW: 12 and 13, male upperside and underside "Barrington Tops, NSW, 23 Jan. 1987, J.F.R. Kerr" (ANIC), 14 and 15, female upperside and underside "Barrington Tops, NSW, 23 Jan. 1987, J.F.R. Kerr" (ANIC); (16-18) N. hobartensis monticola lectotype male (AMS) showing upperside, underside and labels. 


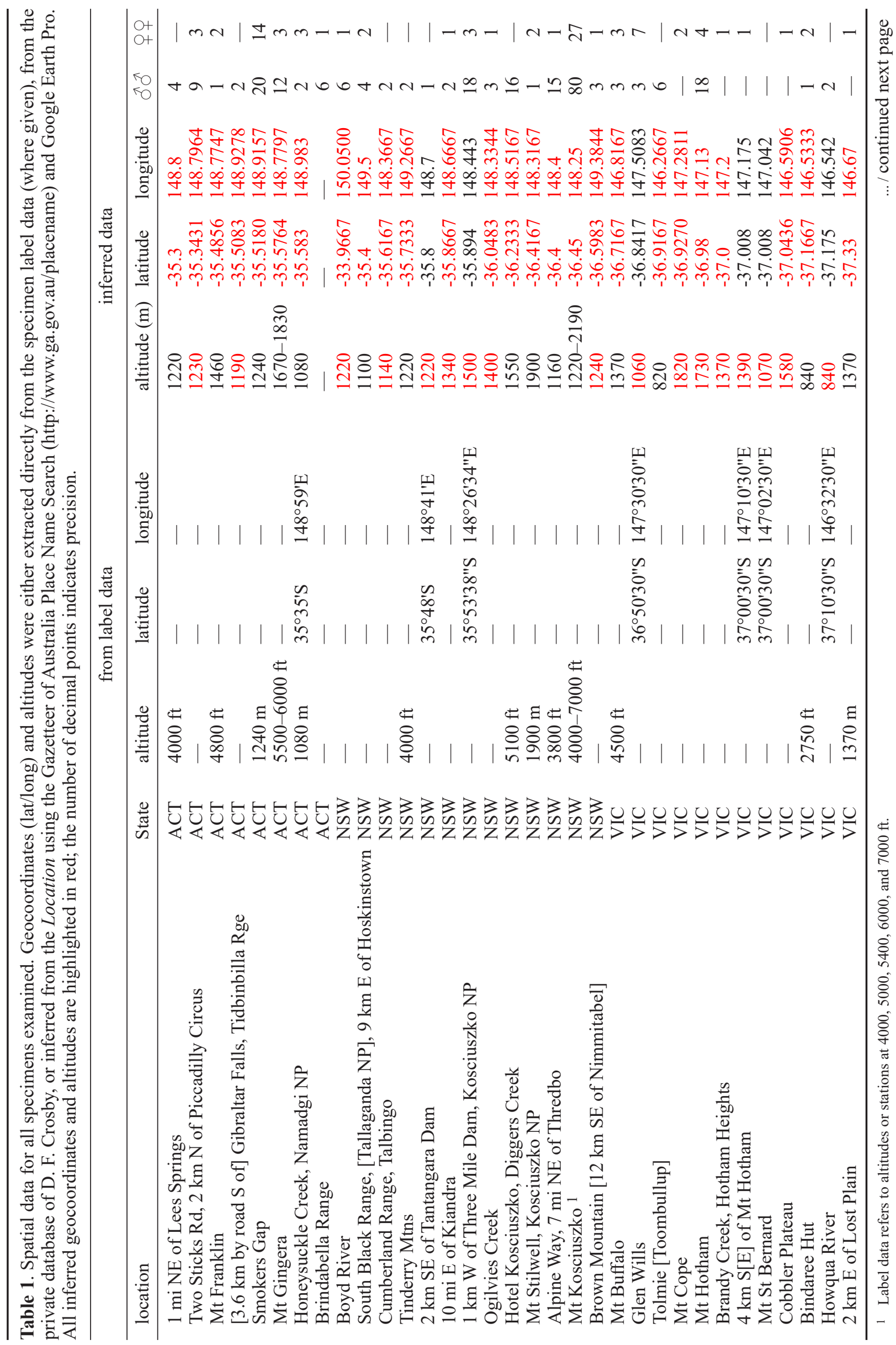




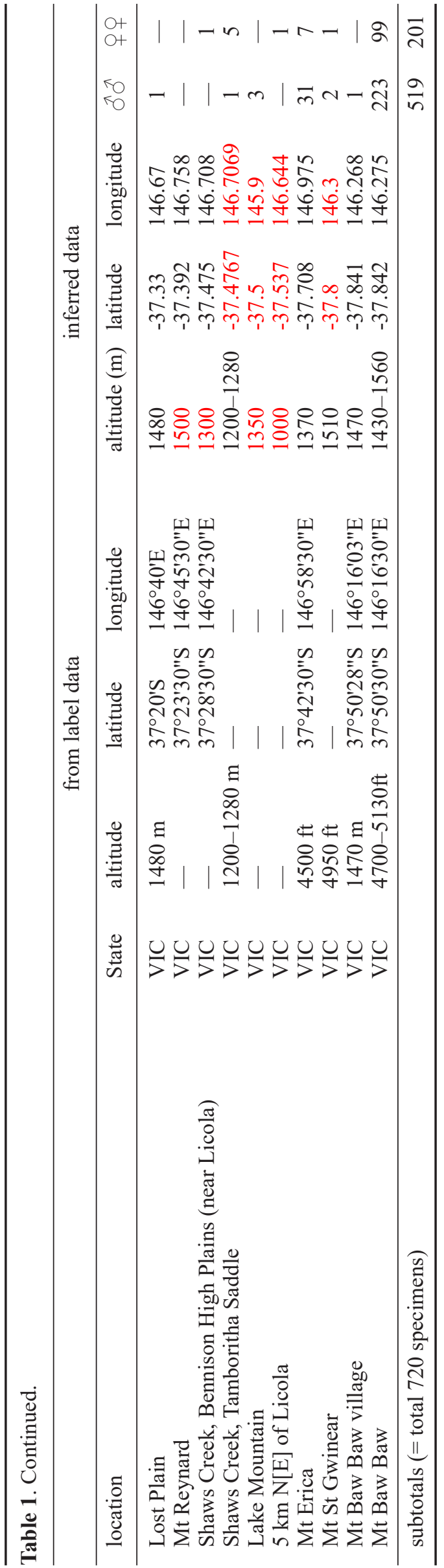

Dam, Kosciuszko NP (180', 3\%); Ogilvies Creek (30', 19); Hotel Kosciuszko, Diggers Creek (160', 29); Mt Stilwell, Kosciuszko NP (10", 19); Alpine Way, 7 mls NE of Thredbo

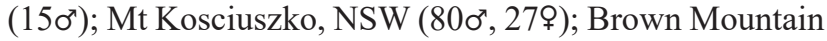
[near Nimmitabel] $\left(30^{\circ}, 1\right.$ ) ). Victoria: Mt Buffalo (30",

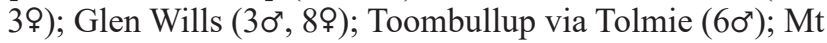

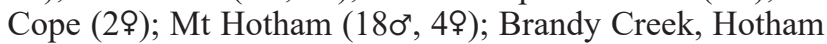
Heights (19); $4 \mathrm{~km} \mathrm{S[E]} \mathrm{of} \mathrm{Mt} \mathrm{Hotham} \mathrm{(19);} \mathrm{Cobbler} \mathrm{Plateau}$ (19); Bindaree Hut / Howqua River (30', 29); Lost Plain (10'); $2 \mathrm{~km}$ E of Lost Plain (19); Shaw's Creek, Tamboritha Saddle / Bennison High Plains $\left(160^{\circ}, 69\right) ; 5 \mathrm{~km} \mathrm{~N}[\mathrm{E}]$ of

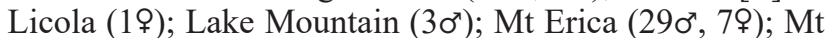
St Gwinear (20', 19); Mt Baw Baw (2230', 999). It has also been collected from Mt St Bernard (10 $\sigma^{\top}$ ) and Mt Reynard $\left(10^{\top}\right)$, VIC (D.F. Crosby, pers. comm.).

Diagnosis. Neolucia hobartensis albolineata is distinguished from $N$. hobartensis hobartensis (Figs 1, 2, 4-7) by the following four character states: (a) specimens of both sexes are substantially larger than those of $N$. hobartensis hobartensis; (b) the underside ground colour of the fore wing in males is greyish-brown, with the markings usually more distinct, particularly the postmedian band which is often more contrasted (darker) against the ground colour and conspicuously edged with dark brown and then white, whereas in $N$. hobartensis hobartensis the ground colour is grey, with the markings generally more obscure or less contrasting. This character, however, is not applicable in females. (c) The white postmedian band or patch on the underside of the hind wing in both sexes is broader and more conspicuous, whereas in $N$. hobartensis hobartensis the white band or patch is often absent; when present it is substantially smaller in extent and less clearly defined; $(d)$ the markings on the underside of the hind wing in males, particularly the subbasal and median series of spots, are generally more distinct, being darker brown against a white ground colour, although this character is variable in both $N$. hobartensis albolineata and $N$. hobartensis hobartensis and is not applicable in females. In $N$. hobartensis albolineata, the ground colour of the basal area of the hind wing may be broadly white, a feature that is absent in both $N$. hobartensis hobartensis and $N$. hobartensis monticola.

Neolucia hobartensis monticola (Figs 12-17) is similar in size to $N$. hobartensis albolineata, but it differs in having the underside ground colour of the fore wing and basal area of the hind wing brown, and the white postmedian band or patch on the underside of the hind wing absent or smaller in extent and less clearly defined. The extensive brown underside ground colour is diagnostic of $N$. hobartensis monticola and this feature no doubt contributed to Waterhouse \& Lyell's (1914, p. 108) conclusion that the subspecies is "much darker both above and beneath". Dissection and examination of the male genitalia of two specimens of each subspecies revealed no significant differences between $N$. hobartensis hobartensis, $N$. hobartensis albolineata and $N$. hobartensis monticola.

Description. The species Neolucia hobartensis has been adequately described and illustrated previously, by Waterhouse \& Lyell (1914), Common \& Waterhouse (1981) and Braby (2000); hence, only a brief description is provided here for Neolucia hobartensis albolineata.

Male. Fore wing length $12.0 \mathrm{~mm}$ (holotype). Upperside dark bronzy-brown, with scale-fringe chequered dark brown 


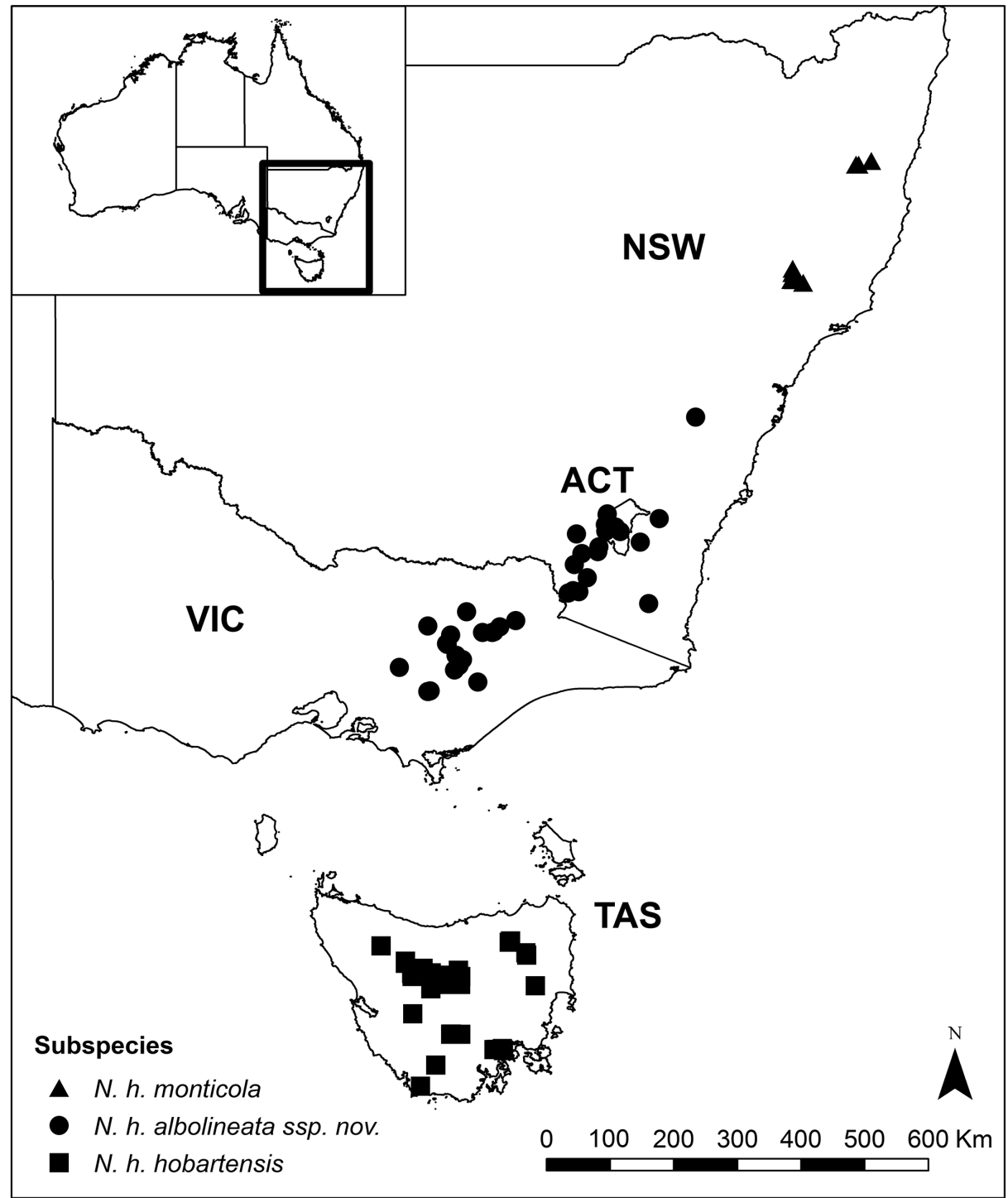

Figure 19. Map of southeastern Australia showing geographical distribution of Neolucia hobartensis. Records for $N$. hobartensis albolineata ssp. nov. are based on museum specimen material examined in this study, whereas those for $N$. hobartensis hobartensis and N. hobartensis monticola are from the Atlas of Living Australia (biocache.ala.org.au accessed 1 May 2018)

and white. Fore wings covered with long hairs (androconia) parallel to veins. Underside of fore wing ground colour grey-brown, with a series of slightly darker markings edged narrowly with dark brown and white, markings comprise a subbasal spot and a larger median spot in discal cell, an obscure median spot above vein $1 \mathrm{~A}+2 \mathrm{~A}$ and a conspicuous postmedian band from above vein $\mathrm{M}_{1}$ to below vein $\mathrm{CuA}_{2}$, followed by one or two obscure dark subterminal bands, and a narrow brown-black terminal line; hind wing with a series of dark brown subbasal and median spots or markings which often coalesce, edged narrowly with black and usually broadly surrounded with white, followed by a prominent white postmedian band or patch, usually two indistinct black inverted V-shaped subterminal marks, and a narrow black terminal line.

Female. Fore wing length 9.6-11.4 mm (paratypes). Similar to male, but upperside without androconia; underside ground colour paler with markings more distinct, and termen of wings more rounded.

Variation. Specimens from the Kosciuszko Plateau, NSW, particularly near the summit of Mt Kosciuszko (1900-2190 $\mathrm{m})$, are unusual. They are smaller in size, paler brown, and the underside markings of the hind wing frequently lack the distinct contrasting pattern of spots and the conspicuous white postmedian band or patch is often absent or substantially reduced in extent. In many respects they resemble $N$. hobartensis hobartensis or $N$. mathewi (Miskin, 1890). Further investigation of this high altitude population is warranted to determine if the distinct phenotype has a genetic or environmental basis.

Remarks. Neolucia hobartensis was originally described by Miskin (1890) under the name Lycaena hobartensis Miskin, 1890 from Tasmania, with Mt Wellington near Hobart the type locality (Waterhouse, 1928). Miskin (1890, pp. 38-39) did not designate a type in the original description, which may have been based on a single specimen (but see Hancock, 1995). Waterhouse (1928) referred to a type, and Couchman (1956) referred to a holotype, though gave the sex as female, and referred to a second specimen. Hancock (1995) referred to a syntype male in the QM and gave label data. Edwards 


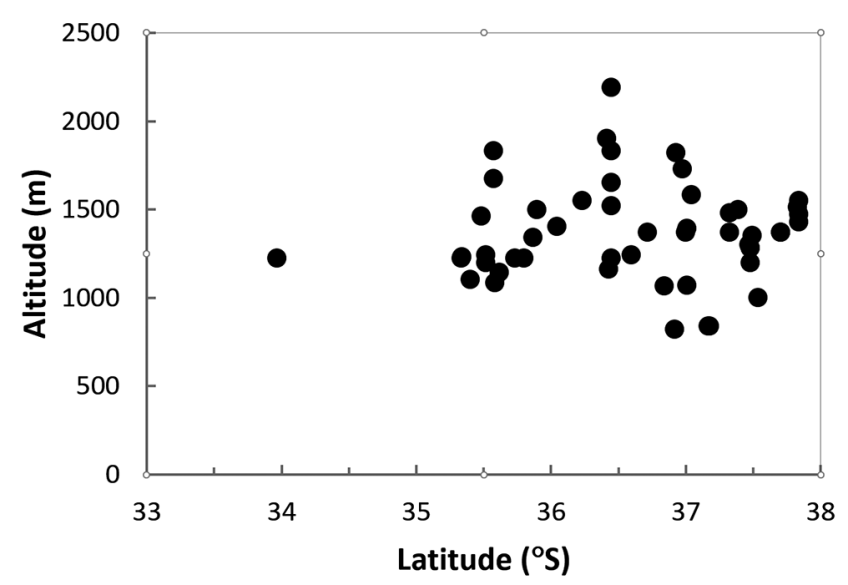

Figure 20. Scatter plot of altitude against latitude for each location of Neolucia hobartensis albolineata ssp. nov. based on specimen label data in the ANIC, NMV and GEWC.

et al. (2001) interpreted Waterhouse's reference to a type as a lectotype designation. The lectotype male is illustrated in Figs 1-3.

Twenty-four years after Miskin's description, Waterhouse \& Lyell (1914) described the subspecies Neolucia hobartensis monticola Waterhouse \& Lyell, 1914 based on a series of specimens from Ebor, NSW (90', 10\%). Waterhouse \& Lyell (1914) illustrated a syntype male (figure 831), but they did not designate a type in the original description. Peters (1971) subsequently referred to a holotype in the AMS and provided a registration number (KL.25037). Edwards et al. (2001) interpreted Peter's incorrect reference to a holotype as a lectotype designation. We have examined the lectotype male (Figs 16-18) and the 18 paralectotypes in AMS and they agree with Waterhouse \& Lyell's (1914) concept of $N$. hobartensis monticola.

It is perhaps surprising that the new geographically intermediate subspecies described herein was overlooked by G. A. Waterhouse, and has since remained unrecognized for more than 100 years since the revisionary work of Waterhouse \& Lyell (1914) given the large number of specimens (721) available in public museums and the private collection of GEW from a relatively accessible and well-collected region of Australia. However, Waterhouse \& Lyell's (1914) description of $N$. hobartensis monticola and examination of the G. A. Waterhouse collection in AMS revealed that in the early 1900's the diagnosis of $N$. hobartensis monticola was based chiefly on comparison of their material from Ebor with specimens from only four other locations: New South Wales (220', $59 \mathrm{Mt}$ Kosciuszko), Victoria (3o', $19 \mathrm{Mt}$ Erica; 1 $\sigma^{\circ}, 19 \mathrm{Mt}$ Hotham) and Tasmania (50' Mt Wellington). Thus, it is clear that of the material in AMS G. A. Waterhouse placed under $N$. hobartensis hobartensis the vast majority (71\%) came from Mt Kosciuszko, most of which was collected by himself during an expedition in 27-29 January 1906 (Edwards, 2002). However, as noted above, material from the Kosciuszko Plateau is not typical of $N$. hobartensis albolineata elsewhere on the Australian mainland: although this population is variable, the specimens are generally smaller and paler and a large proportion (c. 60\%) lack the diagnostic white patch on the underside of the hind wing. Thus, comparison of this anomalous high altitude population with typical $N$. hobartensis hobartensis from Mt Wellington would explain lack of recognition of the southern mainland populations as being taxonomically distinct from the Tasmanian populations at that time.

Etymology. The name albolineata is derived from the Latin word albus, which means white, and the Latin word lineatus, which means lined, and refers to the broad white postmedian line or band on the underside of the hind wing. The species group name is thus a compound descriptive name comprising an adjective-adjective combination with the ending of the second name in feminine form to agree with the gender of the generic name (Neolucia) with which it is combined, according to Article 31.2 of the International Code of Zoological Nomenclature (1999).

Distribution. Neolucia hobartensis albolineata occurs in southeastern Australia where it has a patchy distribution in the southeastern highlands of the mainland along and adjacent to the Great Dividing Range. It extends from the South Black Range in Tallaganda National Park east of Hoskinstown, NSW (Braby, 2000) and the Brindabella Range (1.5 km NE of Lees Spring south of Mt Coree), ACT (Kitching et al., 1978), southwest to Mt Baw Baw (Quick, 1973) and Lake Mountain (Quick, 1973), VIC (Fig. 19). The record further north from the Boyd River, NSW $(1220 \mathrm{~m})$ (E. D. Edwards), represents a disjunct population located approximately $170 \mathrm{~km}$ NNE of Hoskinstown. The subspecies is restricted to montane areas, mainly above 1000 $\mathrm{m}$, although a plot of available specimen data indicates no clear relationship between altitude and latitude across the geographical range of $N$. hobartensis albolineata $(r=0.072$, $P>0.05$ ) (Fig. 20). Most specimens have been collected at altitudes between $1100-1800 \mathrm{~m}$. The only records above $1900 \mathrm{~m}$ are from the Kosciuszko Plateau, NSW, which represents the highest altitude occurrences (up to $2190 \mathrm{~m}$ ) within the geographic range of $N$. hobartensis albolineata. The only records below $1000 \mathrm{~m}$ that we are aware of are the series of specimens $\left(3 \sigma^{\circ}, 2 \%\right)$ from Bindaree Hut / Howqua River, VIC (840 m), collected by the late W. N. B. Quick and D. F. Crosby on 3 Dec. 1972, and another series (6o') from Toombullup near Tolmie, VIC $(820 \mathrm{~m})$, collected by M. F. Braby on 17 Dec. 1983.

The published record further east of the Boyd River from Medlow Barth near Kanangra Walls in the Blue Mountains, NSW (1060 m) by Edwards (1963) is erroneous-the specimens collected are actually $N$. agricola (Westwood, 1851) (E. D. Edwards, pers. comm). Material (20') in the ANIC from the low altitude town of "Valencia Creek, VIC" collected by D.F. Crosby on 15 NOV. 1961 is erroneous and refers to Mt Erica (D.F. Crosby, pers. comm. 2018). A female specimen in AMS labelled "Mylor, S. Australia, 30 Nov. 1902 | 023”, “G. A. Waterhouse Collection", "KL24887”, and a male in AMS labelled "Woodside, S. Aust., M. W. Mules", "Nov - 22nd 1933", "G. A. Waterhouse Collection", "KL24890" are considered to be erroneous. The species is not known to occur in the Mt Lofty Ranges near Adelaide, SA.

Biology. The biology of the subspecies, including descriptions or illustrations of the immature stages, life history and developmental times, has been well documented (Quick, 1973; Common \& Waterhouse, 1981; Braby, 2000; Field, 2013; Bond, 2016). The larvae specialize on 
the flowers and new foliage of Epacris spp. (Ericaceae), including E. petrophila Hook.f., E. breviflora Stapf and E. paludosa $\mathrm{R}$.Br., growing in subalpine and alpine heathland or heathy open-woodland on acidic soils, especially along edges of swamps or along boggy creeks. The life cycle has an embryonic diapause that persists for about nine months of the year, mainly from autumn to spring.

The larval food plant of $N$. hobartensis hobartensis in Tasmania is Epacris serpyllifolia R.Br. (Virtue \& McQuillan, 1994), whereas that of $N$. hobartensis monticola in northern New South Wales has not previously been identified. Waterhouse (1932, p. 170) reported the food plant for the latter subspecies in only general terms "... at Barrington Tops in January, this butterfly was very plentiful at the edges of the swamps, where two species of Epacris were growing. By beating these, I obtained a number of nearly full-grown larvae. These were all feeding on the Epacris with yellowish-green leaves and small white flowers." Since Waterhouse's observations, the species-level identity of the larval food plant of $N$. hobartensis monticola has remained undetermined. However, during a visit to Barrington Tops National Park, NSW the food plant was determined to be Epacris rhombifolia (L.R.Fraser \& Vickery) Menadue-at Polblue Swamp (1450 m) adults flew in close proximity to this shrub growing along the edge of open swampland, and a female was observed on two occasions to lay eggs on the stems above the leaf axils on 27 January 2018 (M. F. Braby, unpublished data).

\section{Discussion}

The subspecies described herein fits the criteria proposed by Braby et al. (2012) for subspecies delineation of butterflies, namely the taxon is allopatric, phenotypically distinct (in colour pattern and morphology), and has at least one fixed diagnosable character state. We assume the taxon represents a partially isolated lineage from $N$. hobartensis hobartensis and $N$. hobartensis monticola and that the character state differences are correlated with evolutionary independence according to population genetic structure. The Bass Strait, which separates $N$. hobartensis albolineata and $N$. hobartensis hobartensis, is a well-known biogeographical barrier for many species distributed on the mainland and Tasmania; the two landmasses have been divided by an extensive water-body for the past 13,000 years (White, 1994), causing reproductive isolation for terrestrial species with limited dispersal capacity. Similarly, the Cassillis Gap, which separates $N$. hobartensis albolineata and $N$. hobartensis monticola, has been a biogeographical barrier for butterflies and other biota since the late Pleistocene, impeding gene flow between populations north of the Gap (Barrington Tops) and those south of the Gap (Blue Mountains) (Eastwood et al., 2006).

Australia is a relatively flat country and is not renowned for its mountains (Australia's highest Mountain, Mt Kosciuszko, is 2,228 m), which are eroded and low in elevation (White, 1994) in comparison with other continents. The greatest topographic relief occurs in the southeast of the continent where butterfly endemism at the species and subspecies level is more pronounced, particularly among the Trapezitinae (Hesperiidae) and Coenonymphina (Nymphalidae: Satyrinae) and to a lesser extent the Theclinae-Polyommatinae assemblage (Lycaenidae) (New, 1999; Braby, 2000), highlighting the importance of the southern Great Dividing Range in the evolution of the Australian butterfly fauna. Thus, Neolucia hobartensis albolineata is one of a set of 22 butterfly taxa that are endemic and narrowly restricted to montane areas (>600 m, but mainly $>900 \mathrm{~m}$ ) in the tablelands and plateaus of mainland southeastern Australia (Table 2). Interestingly, the larvae of many of these montane endemic taxa (all Trapezitinae and Satyrinae) specialize on monocots, particularly Poaceae and Cyperaceae.

Further work is needed to assess the conservation status of all of these narrow-range montane endemics because their restricted high altitudinal distribution, with frequently disjunct occurrences on isolated mountain ranges and plateaus of and near the Great Dividing Range, implies that they may be susceptible to global climate change, particularly changes in temperature (Parmesan et al., 1999; New, 2011). During the past century the global average surface temperature has increased by $0.6^{\circ} \mathrm{C}$ (Australia has warmed c. $0.8^{\circ} \mathrm{C}$ over this period), with much of this increase occurring during the last three decades, and further substantial rises in temperature are projected over the next 50 years (IPCC, 2001, 2007). Australian butterflies are expected to respond to these temperature changes because, being ectotherms, their metabolic and developmental rates are temperaturedependent. These responses include changes in spatial distribution (altitude or latitude), phenology (e.g., adult emergence time, flight period) and adaptation, all of which may affect levels of abundance and ecological interactions with other species, and may lead to extinction of local populations (Hughes, 2000, 2003; Beaumont \& Hughes, 2002; Beaumont et al., 2005). For example, a $1^{\circ} \mathrm{C}$ rise in mean annual temperature corresponds to a shift in isotherms of approximately $160 \mathrm{~m}$ in elevation or $100-130 \mathrm{~km}$ in latitude in the temperate zone (Hughes, 2000). Therefore, species are expected to move upwards in elevation or polewards in latitude in response to shifting climate zones. Indeed, global meta-analyses of 99 species have revealed significant upward shifts in altitudinal range, averaging 6.1 m per decade (Parmesan \& Yohe, 2003).

Although the altitudinal range $N$. hobartensis albolineata is quite large (1370 $\mathrm{m}$ over $4^{\circ}$ latitude), the taxon has limited capacity to expand upward and/or poleward (southward) because it already occurs near the summit of Mt Kosciuszko and at the southern limit of the Australian Alps (Mt Erica and Mt Baw Baw). Thus, the lower altitude limit of the range (820-840 $\mathrm{m}$, as of 1972-1983) is more likely to be severely impacted and retract upward by global climate change, if it hasn't already. Any contraction in altitudinal range, however, will lead to substantial population isolation and fragmentation because of the discontinuous nature and comparatively low altitude of the montane country in southeastern Australia. Some populations, such as the Boyd River $(1220 \mathrm{~m})$, occur at their altitudinal maxima and essentially have no capacity to move upwards. Long-term monitoring of all populations of all subspecies of $N$. hobartensis is therefore required to assess how the species responds to global climate change and whether mitigating actions are needed to safeguard its future survival. Indeed, two decades ago Crosby (1998) recommended that monitoring populations of $N$. hobarensis and other alpine butterflies restricted to the Mount Buffalo 
Table 2. Butterfly taxa endemic to montane areas (>c. $600 \mathrm{~m}$ altitude) on the mainland in southeastern Australia; compiled from data in Common \& Waterhouse (1981), Braby (2000, 2016), Johnson \& Wilson (2005), Sands \& Sands (2017) and M. F. Braby and J. J. Armstrong (unpublished data).

\begin{tabular}{|c|c|c|c|}
\hline species & altitude (m) & distribution & larval food plants \\
\hline \multicolumn{4}{|l|}{ HESPERIIDAE: TRAPEZITINAE } \\
\hline Anisynta tillyardi & $900-1500$ & $\begin{array}{l}\text { Bunya Mtns, QLD to } \\
\text { Barrington Tops, NSW }\end{array}$ & $\begin{array}{l}\text { Poa labillardieri, P. queenslandica, } \\
\text { P. sieberiana, P. tenera (Poaceae) }\end{array}$ \\
\hline Anisynta cynone anomala & $1080-1210$ & New England Tableland, NSW & Poa sp. (Poaceae) \\
\hline a Anisynta monticolae & $600-1500$ & $\begin{array}{l}\text { Blue Mountains, NSW to } \\
\text { Black Range, VIC }\end{array}$ & Poa tenera (Poaceae) \\
\hline Anisynta dominula dominula & $600-1670$ & $\begin{array}{l}\text { New England Tableland, NSW } \\
\text { to Mt Donna Buang, VIC }\end{array}$ & Poa sp. (Poaceae) \\
\hline Oreisplanus munionga munionga & $1060-1600$ & $\begin{array}{l}\text { Barrington Tops, NSW to } \\
\text { Mt Buller, VIC }\end{array}$ & $\begin{array}{l}\text { Carex appressa, C. longibrachiata, } \\
\text { Scirpus polystachyus (Cyperaceae) }\end{array}$ \\
\hline Hesperilla crypsargyra binna & 840 & Lamington Plateau, QLD & Gahnia insignis (Cyperaceae) \\
\hline Hesperilla hopsoni & $1280-1500$ & $\begin{array}{l}\text { Near Stanthorpe, QLD to } \\
\text { Barrington Tops, NSW }\end{array}$ & $\begin{array}{l}\text { Gahnia sieberiana, G. grandis } \\
\text { (Cyperaceae) }\end{array}$ \\
\hline Mesodina aeluropis & $820-1270$ & $\begin{array}{l}\text { New England Tableland to } \\
\text { Kosciuszko NP, NSW }\end{array}$ & Patersonia sp. aff. sericea (Iridaceae) \\
\hline \multicolumn{4}{|l|}{ NYMPHALIDAE: SATYRINAE } \\
\hline Tisiphone abeona regalis & $900-1370$ & $\begin{array}{l}\text { Near Stanthorpe, QLD to } \\
\text { Barrington Tops, NSW }\end{array}$ & Gahnia spp. (Cyperaceae) \\
\hline Oreixenica orichora orichora & $1200-2100$ & $\begin{array}{l}\text { Brindabella Range, ACT to } \\
\text { Mt Tamboritha, VIC }\end{array}$ & Poa fawcettiae, P. hiemata (Poaceae) \\
\hline Oreixenica correae & $1200-1800$ & $\begin{array}{l}\text { Brindabella Range, ACT to } \\
\text { Mt Donna Buang, VIC }\end{array}$ & Poa ensiformis, P. hiemata (Poaceae) \\
\hline Oreixenica kershawi ella & $900-1450$ & Barrington Tops, NSW & Poaceae \\
\hline Oreixenica latialis latialis & $1200-1800$ & $\begin{array}{l}\text { Boyd River, NSW to } \\
\text { Mt Tamboritha, VIC }\end{array}$ & Poa hiemata (Poaceae) \\
\hline Oreixenica latialis theddora & $1230-1370$ & Mt Buffalo plateau, VIC & Poa sp. (Poaceae) \\
\hline b Heteronympha solandri & $840-1600$ & $\begin{array}{l}\text { Boyd River, NSW to } \\
\text { Grampians, VIC }\end{array}$ & $\begin{array}{l}\text { Poa labillardieri, Tetrarrhena } \\
\text { juncea (Poaceae) }\end{array}$ \\
\hline Heteronympha banksii mariposa & $600-900$ & $\begin{array}{l}\text { Bunya Mnts to Macpherson } \\
\text { Range and nr Stanthorpe, QLD }\end{array}$ & $\begin{array}{l}\text { Poa labillardieri, P. queenslandica, } \\
\text { P. sieberiana, P. tenera (Poaceae) }\end{array}$ \\
\hline \multicolumn{4}{|l|}{ LYCAENIDAE } \\
\hline Acrodipsas aurata & $580-1060$ & $\begin{array}{l}\text { Blue Mountains, NSW to } \\
\text { Pine Mountain, VIC }\end{array}$ & Crematogaster ants \\
\hline Pseudalmenus chlorinda barringtonensis & $1200-1580$ & $\begin{array}{l}\text { Mt McKenzie to } \\
\text { Barrington Tops, NSW }\end{array}$ & $\begin{array}{l}\text { Acacia dealbata, A. melanoxylon, } \\
\text { A. irrorata (Fabaceae) }\end{array}$ \\
\hline Candalides heathi doddi & $1300-1340$ & $\begin{array}{l}\text { New England Tableland to } \\
\text { Barrington Tops, NSW }\end{array}$ & Veronica perfoliata (Plantaginaceae) \\
\hline Candalides heathi alpinus & $700-1820$ & $\begin{array}{l}\text { South Black Range, NSW to } \\
\text { Dellicknora, VIC }\end{array}$ & $\begin{array}{l}\text { Veronica derwentiana, } V \cdot \text { perfoliata } \\
\text { (Plantaginaceae) }\end{array}$ \\
\hline Neolucia hobartensis monticola & $1200-1450$ & $\begin{array}{l}\text { Dorrigo Plateau to } \\
\text { Barrington Tops, NSW }\end{array}$ & Epacris rhombifolia (Ericaceae) \\
\hline Neolucia hobartensis albolineata ssp. nov. & $820-2190$ & $\begin{array}{l}\text { Boyd River, NSW to } \\
\text { Mt Baw Baw, VIC }\end{array}$ & $\begin{array}{l}\text { Epacris petrophila, E. breviflora, } \\
\text { E. paludosa (Ericaceae) }\end{array}$ \\
\hline
\end{tabular}

a The population of Anisynta monticolae in western Victoria in the Black Range State Park near the Grampians occurs at lower altitudes ( $>400 \mathrm{~m})$.

b Disjunct populations of Heteronympha solandri in western and southwestern Victoria occur at lower altitudes (320-640 m, but generally $>500 \mathrm{~m})$, with those from the Otway Range representing an undescribed taxon (Braby, 2000). 
plateau, VIC, was required to assess the impact of global climate change, especially rising temperatures. Laboratory studies investigating the degree of physiological tolerance and adaption to temperature variation are also required, including the cues inducing, maintaining and terminating egg diapause.

Related to global climate change, another potential threat facing $N$. hobartensis albolineata that needs further investigation is the increasing scale and frequency of mega fire events in southeastern Australia, such as the Canberra bushfires (18-22 January 2003) that destroyed most of the montane forests of the Australian Capital Territory and adjacent mountains in New South Wales (e.g., Kosciuszko National Park), and the Black Saturday bushfires (7 February 2009) that devastated large areas of mountainous habitat of the butterfly in Victoria. These events, and subsequent prescribed burning practices, are likely to have a detrimental effect on insects (New et al., 2010). It is not known how butterflies such as $N$. hobartensis albolineata recover from such catastrophic events or what time interval is required for habitats to reach a state of ecological succession suitable for breeding post-fire. Presumably the butterfly recolonizes regrowth areas, but this clearly depends on: (a) the extent of refuges (spatial mosaics of unburnt patches) within the landscape, and (b) the dispersal capability of adults. Given the patchy and discontinuous nature of much of the species' habitat over the mountains of southeastern Australia, longdistance dispersal events between mountain peaks/plateaus are probably rare. Species of Epacris show a range of adaptive responses to disturbance such as high intensity fire, including resprouting from woody rootstock or basal lignotuber and regenerating from soil-stored seed after death of the parent plant with seedlings requiring at least three years to flower and set fruit (Benson \& McDougall, 1995). Among the known larval food plants of $N$. hobartensis albolineata, E. paludosa and E. breviflora resprout after fire (Benson \& McDougall, 1995; K. McDougall, pers. comm.), whereas $E$. petrophila is killed and recruitment may be poor following high intensity fire (K. McDougall, pers. comm.). Thus, $N$. hobartensis albolineata may be at further risk because of its ecological dependency on Epacris spp. growing in subalpine and alpine swampland habitats - obligate seeders such as $E$. petrophila may be diminished or possibly eliminated if the fire frequency is too high, and adult dispersal may be limited for recolonization if the spatial distance between unburnt patches is large following large-scale catastrophic fire events.

AcKNOWLEDGMENTs. We are grateful to Geoff Thompson (QM), You Ning Su (ANIC) and Natalie Tees (AMS) for providing images of Neolucia hobartensis, including type material, Simon Hinkley (NMV) and Derek Smith and Russell Cox (AMS) for access to specimens in museums under their care, David Crosby for clarification of specimen records from Victoria, and Ted Edwards, David Cameron, Rod Eastwood and Tim New for critically reading a draft of the manuscript. David Albrecht kindly helped with botanical literature and identified the larval food plant of $N$. hobartensis monticola from Barrington Tops, and Keith McDougall provided unpublished observations on the reproductive biology of Epacris.

\section{References}

Beaumont, L. J., and L. Hughes. 2002. Potential changes in the distributions of latitudinally restricted Australian butterfly species in response to climate change. Global Change Biology 8: 954-971.

https://doi.org/10.1046/j.1365-2486.2002.00490.x

Beaumont, L. J., L. Hughes, and M. Poulsen. 2005. Predicting species distributions: use of climatic parameters in BIOCLIM and its impact on predictions of species' current and future distributions. Ecological Modelling 186: 250-269. https://doi.org/10.1016/j.ecolmodel.2005.01.030

Benson, D., and L. McDougall. 1995. Ecology of Sydney Plant Species: Part 3: Dicotyledon families Cabombaceae to Eupomatiaceae. Cunninghamia 4: 217-431.

Bond, S. 2016. Field Guide to the Butterflies of the Australian Capital Territory. Canberra: National Parks Association of the ACT Inc.

Braby, M. F. 2000. Butterflies of Australia. Their Identification, Biology and Distribution. Collingwood, Melbourne: CSIRO Publishing.

Braby, M. F. 2016. The Complete Field Guide to Butterflies of Australia. Second Edition. Melbourne: CSIRO Publishing.

Braby, M. F., R. G. Eastwood, and N. Murray. 2012. The subspecies concept in butterflies: has its application in taxonomy and conservation biology outlived its usefulness? Biological Journal of the Linnean Society 106: 699-716. https://doi.org/10.1111/j.1095-8312.2012.01909.x

Common, I. F. B., and D. F. Waterhouse. 1981. Butterflies of Australia. Revised edn. Sydney: Angus and Robertson.

Couchman, L. E. 1956. A catalogue of the Tasmanian LepidopteraRhopalocera. Papers and Proceedings of the Royal Society of Tasmania 90: 1-33.

Couchman, L. E., and R. Couchman. 1977. The butterflies of Tasmania. Tasmanian Year Book, 1977 11: 66-96, 6 pls.

Crosby, D. F. 1998. The butterflies of Mount Buffalo National Park. The Victorian Naturalist 115: 222-225.

Eastwood, R. G., N. E. Pierce, R. L. Kitching, and J. M. Hughes. 2006. Do ants enhance diversification in lycaenid butterflies? Phylogenetic evidence from a model myrmecophile, Jalmenus evagoras. Evolution 60: 315-327. https://doi.org/10.1111/j.0014-3820.2006.tb01109.x

Edwards, E. D. 2002. Lepidoptera (Moths and Butterflies). In Biodiversity in the Snowy Mountains, ed K. Green, pp. 58-72. Jindabyne: Australian Institute of Alpine Studies.

Edwards, E. D., J. Newland, and L. Regan. 2001. Lepidoptera: Hesperioidea, Papilionoidea. Zoological Catalogue of Australia. Vol. 31.6. Collingwood, Melbourne: CSIRO Publishing.

Edwards, E. O. E. 1963. Some new locality records of butterflies. Australian Zoologist 13: 29.

Espeland, M., J. W. Breinholt, K. R. Willmott, A. D. Warren, R. Vila, E. F. A. Toussaint, S. C. Maunsell, K. Aduse-Poku, G. Talavera, R. G. Eastwood, M. A. Jarzyna, R. Guralnick, D. J. Lohman, N. E. Pierce, and A. Y. Kawahara, 2018. A comprehensive and dated phylogenomic analysis of butterflies. Current Biology 28: $770-778$. https://doi.org/10.1016/j.cub.2018.01.061

Field, R. P. 2013. Butterflies: Identification and Life History. Melbourne: Museum Victoria.

Hancock, D. L. 1995. The butterfly types of W.H. Miskin in the Queensland Museum (Lepidoptera). Memoirs of the Queensland Museum 38: 519-528.

Hirowatari, T. 1992. A generic classification of the Tribe Polyommatini of the Oriental and Australian Regions (Lepidoptera, Lycaenidae, Polyommatinae). Bulletin of the University of Osaka Prefecture, Series B 44 (Supplement): $1-102$. 
Hughes, L. 2000. Biological consequences of global warming: is the signal already. Trends in Ecology \& Evolution 15: 56-62. https://doi.org/10.1016/S0169-5347(99)01764-4

Hughes, L. 2003. Climate change and Australia: Trends, projections and impacts. Austral Ecology 28: 423-443. https://doi.org/10.1046/j.1442-9993.2003.01300.x

International Commission on Zoological Nomenclature. 1999. International Code of Zoological Nomenclature. Fourth Edition. London: The International Trust for Zoological Nomenclature.

IPCC. 2001. Climate Change 2001: The Scientific Basis. Report from Working Group 1. Geneva: Intergovernmental Panel of Climate Change.

IPCC. 2007. Climate Change 2007: Synthesis Report. Contribution of Working Groups I, II and III to the Fourth Assessment Report of the Intergovernmental Panel on Climate Change Geneva, Switzerland: IPCC.

Johnson, S. J., and P. R. Wilson. 2005. A new subspecies of Hesperilla crypsargyra (Meyrick) (Lepidoptera: Hesperiidae) from southern Queensland and a new status for Hesperilla hopsoni Waterhouse. The Australian Entomologist 32: 163-171.

Kitching, R. L., E. D. Edwards, D. Ferguson, M. B. Fletcher, and J. M. Walker. 1978. The butterflies of the Australian Capital Territory. Journal of the Australian Entomological Society 17: $125-133$. https://doi.org/10.1111/j.1440-6055.1978.tb02217.x

Miskin, W. H. 1890. Descriptions of hitherto undescribed Australian Lepidoptera (Rhopalocera) principally Lycaenidae. Proceedings of the Linnean Society of New South Wales 5: 29-43. https://doi.org/10.5962/bhl.part.18623

New, T. R. 1999. The evolution and characteristics of the Australian butterfly fauna. In Biology of Australian Butterflies. Monographs of Australian Lepidoptera. Volume 6, ed. R. L. Kitching, R. E. Jones, E. Scheermeyer, and N. E. Pierce, pp. 33-52. Collingwood, Melbourne: CSIRO Publishing.

New, T. R. 2011. Butterfly Conservation in South-Eastern Australia: Progress and Prospects. Dordrecht: Springer. https://doi.org/10.1007/978-90-481-9926-6

New, T. R., A. L. Yen, D. P. A. Sands, P. Greenslade, P. J. Neville, A. York, and N. G. Collett. 2010. Planned fires and invertebrate conservation in south east Australia. Journal of Insect Conservation 14: 567-574.

https://doi.org/10.1007/s10841-010-9284-4
Parmesan, C., N. Ryrholm, C. Stefanescu, J. K. Hill, C. D. Thomas, H. Descimon, B. Huntley, L. Kaila, J. Kullberg, T. Tammaru, W. J. Tennent, J. A. Thomas, and M. S. Warren. 1999. Poleward shifts in geographical ranges of butterfly species associated with regional warming. Nature 399: 579-583. https://doi.org/10.1038/21181

Parmesan, C., and G. Yohe. 2003. A globally coherent fingerprint of climate change impacts across natural systems. Nature 421: $37-42$.

https://doi.org/10.1038/nature01286

Peters, J. V. 1971. A catalogue of the type specimens of the Hesperioidea and Papilionoidea (Lepidoptera) in the Australian Museum. Sydney, NSW: Australian Entomological Press.

Quick, W. N. B. 1973. Early stages of the "Mountain Blue", Neolucia hobartensis hobartensis (Miskin) 1890 (LepidopteraLycaenidae). Victorian Entomologist 3: 9-10.

Sands, D. P. A., and M. C. Sands. 2017. Description of Anisynta cynone anomala subsp. $\mathrm{n}$. (Lepidoptera: Hesperiidae) from the northern tablelands of New South Wales, with discussion of its variation, sympatry with and similarity to Anisynta tillyardi Waterhouse \& Lyell. The Australian Entomologist 44: 89-102.

Virtue, J., and P. McQuillan. 1994. Butterflies of Tasmania. Hobart: Tasmanian Field Naturalists Club Inc.

Waterhouse, G. A. 1928. Notes on Australian Lycaenidae. Part VI. Proceedings of the Linnean Society of New South Wales 53: 401-412.

Waterhouse, G. A. 1932. What Butterfly is That? Sydney: Angus and Robertson.

Waterhouse, G. A., and G. Lyell. 1914. The Butterflies of Australia. A Monograph of the Australian Rhopalocera. Sydney: Angus and Robertson.

White, M. E. 1994. After the Greening. The Browning of Australia. East Roseville, NSW: Kangaroo Press. 